\title{
EPISODE OF LOW LEVEL JETS IN THE NORTH AND NORTHEAST COAST OF STATE OF PARA: A CASE STUDY OF 2002 APRIL 21ST TO 22ND,
}

\author{
ADRIANO MARLISOM LEÃO SOUSA ${ }^{1}$, CLAUDIA REJANE JACONDINO CAMPOS ${ }^{2}$,EDSON JOSÉ \\ PAULINO ROCHA ${ }^{3}$
}

\author{
${ }^{1}$ Universidade Federal de Pelotas - Programa de Pós-Graduação em Meteorologia. \\ ${ }^{2}$ Universidade Federal de Pelotas · Campus Universitário, Faculdade de Meteorologia \\ ${ }^{3}$ Universidade Federal do Pará - Centro de Geociências - Departamento de Meteorologia. \\ marlisoms@yahoo.com.br
}

Received September 2006 - Accepted June 2008

\begin{abstract}
:
In this study the characteristics of the vertical structure of an episode of Low Level Jets (LLJ) occurring in the coast of Para is described. Radiosonde data of Ajuruteua city in Bragança collected during the DESMATA Experiment (Impact of the Deforestation the Atlantic Coast of the Amazonian), taking place in 2002, from April 08th to 22th, are used. Among the detected cases during the rainy period, one specific case with 12 hours duration, average velocity of $15 \mathrm{~m} / \mathrm{s}$ and directed from NE to E in the point of maximum velocity was selected. The observational results have indicated that this LLJ located in the coast of Para was due to the combined action of two factors: (1) inertial oscillation and (2) superficial baroclinicity. These two combined factors sustained this LLJ with velocities between 10 and $13 \mathrm{~m} / \mathrm{s}$ during the day and between 14 and $16 \mathrm{~m} / \mathrm{s}$ during the night, at an average altitude of $800 \mathrm{~m}$ above surface.
\end{abstract}

Key Words: Low Level Jets, planetary boundary layer, thermal contrast and Amazonian.

RESUMO: EPISÓDIO DE JATOS DE BAIXOS NÍVEIS NO LITORAL NORTE E NORDESTE DO ESTADO DO PARÁ: UM ESTUDO DE CASO DE 21-22 DE ABRIL DE 2002.

Neste estudo descreve-se as características da estrutura vertical de um episódio de Jatos de Baixos Níveis (JBN) ocorrido no litoral do Pará, utilizando-se para tal, dados das radiossondagens de Ajuruteua, Município de Bragança coletados durante o Experimento DESMATA (Impacto do Desmatamento Junto ao Litoral Atlântico da Amazônia) realizado no período de 08 a 22 de abril de 2002. Dentre os casos detectados no período chuvoso, selecionou-se um que se manteve por 12 horas com velocidade média de $15 \mathrm{~m} / \mathrm{s}$ e que estava direcionado de Nordeste para Leste, no ponto de máxima velocidade. Os resultados observacionais indicaram que, este JBN localizado no litoral Paraense foi resultado da ação combinada de dois fatores: (1) oscilação inercial e (2) baroclinia superficial. Estes dois fatores combinados sustentaram este JBN com intensidades entre 10 e $13 \mathrm{~m} / \mathrm{s}$ durante o dia e entre 14 e $16 \mathrm{~m} / \mathrm{s}$ durante a noite, localizado a uma altitude média de $800 \mathrm{~m}$ acima da superfície.

Palavras-chaves: Jatos de baixos níveis, camada limite planetária, contraste térmico e Amazônia. 


\section{INTRODUCTION}

Means $(1952 ; 1954)$ introduced the term Low level Jets (LLJ) to describe a strong area of air flow at level below $700 \mathrm{hPa}$ in the South-central part of the United States. According to this author the LLJ is, at least, partially geostrophic and it occurs in synoptic situations where, an area of warm air moving to west and with strong geostrophic winds coming from south is formed in the surface, decreasing with height.

The LLJ are recognized as a complex answer of the planetary boundary layer to the diurnal cycle of thermal forcing and they present a region of maximum velocity well defined. In this way, the jet can be defined as an atmospheric layer of small thickness in which the drainage of air presents an intense velocity (Wippermann, 1973). The formation of LLJ is due to the acceleration of the drainage associated to the: (a) inertial oscillation; (b) topographic canalization; (c) topographic blocking; (d) baroclinic effect caused by thermal contrasts in the surface; (e) forcing of scale synoptic (Wu and Raman, 1997). Numerical studies show that the thermal contrast generated by the heterogeneity of the surface is one of the main mechanisms responsible for the generation of LLJ (Wu and Raman, 1997).

These jets transport heat and humidity and they are favorable to the formation and intensification of meteorological systems like squall lines. LLJ occurs more frequently during the night period and they contribute in the transport of humidity and, consequently, in the development and in the maintenance of night storms (Whiteman, 1997 and Bonner, 1968a, b). These jets are also found in several parts of the world (Figure1), for example, in Alpes (Paegle et al, 1984), in the superior part of Africa (Farquharson, 1939), and in association with the Squall Lines (SL) in the Amazonian Basin (Cohen et al, 1995).

Based on observations made in the North coast and Northeast of the Para State and on the criterion developed by Bonner (1968) this work has the objective of studying and analysing the vertical structure of an episode of LLJ occurring on 2002, April $21^{\text {st }}-22^{\text {nd }}$, in the East of the Amazonian region. It is necessary to mention that this LLJ was formed during the development of a Squall Line (SL) in the coast of Para and inside the continent.

\section{MATERIALS AND METHOD}

\subsection{Selection of the case study of LLJ}

To select the case of occurrence of LLJ, the profiles of the wind fields from 55 radiosondes were analyzed, using the classification criterion proposed by Bonner (1968) and later modified by Whiteman et al (1997) and Stivari (1999), here referred as B\&WS. B\&WS suggested two criteria of classification that should be satisfied simultaneously: (a) the first, specifies the maximum value of the wind intensity "nucleus of the jet", (b) and the second specifies the decrease of the values of the wind intensity above its nucleus of maximum as far reaching the minimum speed below $3 \mathrm{~km}$ high

After the case selection, the predominant direction,

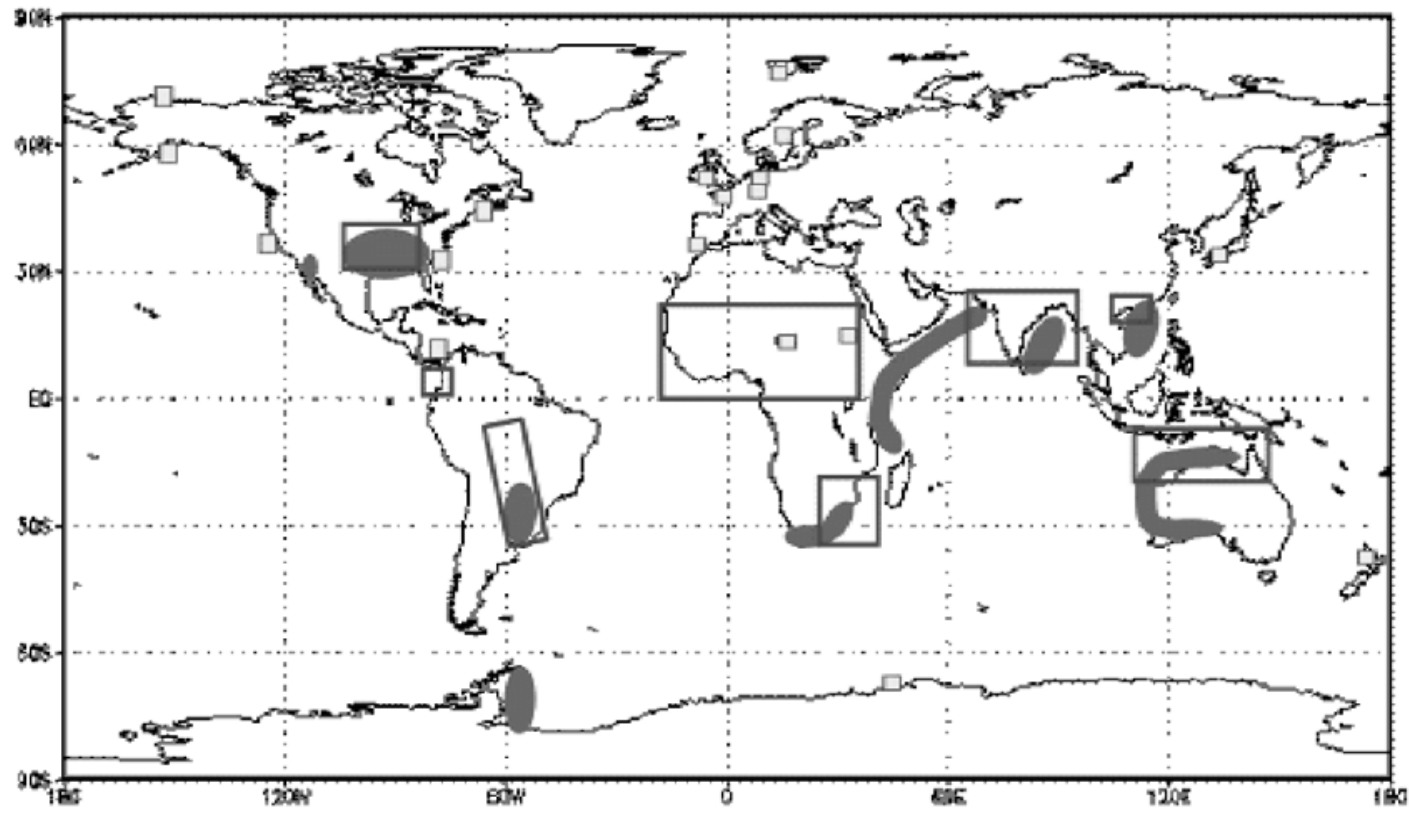

Figure1 - Places of occurrence of LLJ in all world. Source: Stensrud, 1996. 
Table 1 - Criterion of classification for low level jets. (Source: Adapted of Karam, 2002)

\begin{tabular}{clc}
\hline TIPO & \multicolumn{1}{c}{ CRITÉRIO DE CLASSIFICAÇÄO } & REFERENCIAS \\
\hline $\mathrm{J} 0$ & $V_{\max } \geq 10 \mathrm{~m} / \mathrm{s}$ e $\left(V_{\max }-V_{3 \mathrm{~km}}\right) \geq 5 \mathrm{~m} / \mathrm{s}$ & WHITEMAN et al. \\
& & $(1997)$ \\
$\mathrm{J} I$ & $V_{\max } \geq 12 \mathrm{~m} / \mathrm{s}$ e $\left(V_{\max }-V_{3 \mathrm{~km}}\right) \geq 6 \mathrm{~m} / \mathrm{s}$ & \\
$\mathrm{J}$ II & $V_{\max } \geq 16 \mathrm{~m} / \mathrm{s}$ e $\left(V_{\max }-V_{3 \mathrm{~m}}\right) \geq 8 \mathrm{~m} / \mathrm{s}$ & BONNER \\
$\mathrm{J}$ III & $V_{\max } \geq 20 \mathrm{~m} / \mathrm{s}$ e $\left(V_{\max }-V_{3 \mathrm{~km}}\right) \geq 10 \mathrm{~m} / \mathrm{s}$ & $(1968 \mathrm{a})$ \\
$\mathrm{J}$ IV & $V_{\max } \leq 10 \mathrm{~m} / \mathrm{s}$ e $\left(V_{\max }-V_{3 \mathrm{~m}}\right)$ pelo menos a metade da $V_{\max }$ & STIVARI,1999 \\
\hline
\end{tabular}

altitude and the intensity of the observed LLJ was determined. Then, thermodynamic diagrams and hodographs curves were used to analyze the environment in which the LLJ was inserted. Finally linked the LLJ with the occurrence of a squall line through the analysis of satellite images and also the climate analysis was used to observe the environment of great scale.

\subsection{Case study}

Based on the analysis of superior air in the coast of the Para State, and using the criterion proposed by B\&WS for the wind profiles at Ajuruteua (more details at Sousa, 2005), some strong episodes of LLJ were observed during the 2002 rainy period. The episode of LLJ during April 21st-22nd 2002, was related to the fact of the presence of a SL in the coast of Para, this case being developed in the moment of larger activity of SL in the coast of Para. The importance of studying this particular episode of LLJ is that it was maintained for 12 hours acting in the coast and it was stronger during the rainy period of 2002 .

\subsection{Observational Results}

The application of B\&WS criterion to the data collected in the field during the DESMATA Experiment, allowed the selection of the following days, on year 2002, with LLJ occurrence: April 08, 09, 14, 16, 21 and 22 (Table 2). In the sequence, a detailed description of the selected case $\left(21^{\text {st }}\right.$ and $22^{\text {nd }}$ ) for study is presented.

\subsection{Case Study: 2002/April/22}

The configuration of wind profiles revealed that the generation of this LLJ began at 1800UTC on 2002/04/21 (Figure2a), with the starting point around $250 \mathrm{~m}$, its top at $1750 \mathrm{~m}$ and its point of maximum intensity around $1100 \mathrm{~m} \mathrm{high}$ ( $12 \mathrm{~m} / \mathrm{s}$ and SE direction). On April 22, 2002 at 0000 UTC the most intense LLJ of all studied period was detected. This LLJ had intensity of $16.5 \mathrm{~m} / \mathrm{s}$, was located at an altitude of $800 \mathrm{~m}$ (Figure2b) and it was directed to East at level of maximum

\section{RESULTS AND DISCUSSION}

Table 2 - Total of occurrences of LLJ observed in the rainy period below and above of 500m.

\begin{tabular}{|c|c|c|c|c|c|c|c|}
\hline \multicolumn{8}{|c|}{ Abaixo de $500 \mathrm{~m}$ (00 e 06 UTC) } \\
\hline Data & Hora & Inten.(m/s) & $\begin{array}{c}\text { Alt.(m) } \\
\text { Não }\end{array}$ & $\begin{array}{l}\text { Dir. }\left({ }^{\circ}\right) \\
\text { JBN }\end{array}$ & Tipo & Média vv & Média Alt \\
\hline \multicolumn{8}{|c|}{ Acima de $500 \mathrm{~m}$ (00 e 06 UTC) } \\
\hline $\begin{array}{c}\text { Data } \\
09 / 04 / 02 \\
14 / 04 / 02 \\
22 / 04 / 02 \\
22 / 04 / 02\end{array}$ & $\begin{array}{c}\text { Hora } \\
00 \\
00 \\
00 \\
06\end{array}$ & $\begin{array}{c}\text { Inten.(m/s) } \\
7,1 \\
8,4 \\
16,5 \\
13,0\end{array}$ & $\begin{array}{c}\text { Alt.(m) } \\
600 \\
750 \\
800 \\
850\end{array}$ & $\begin{array}{c}\text { Dir. }\left({ }^{\circ}\right) \\
\text { NE } \\
\text { NE } \\
\text { E } \\
\text { E }\end{array}$ & $\begin{array}{c}\text { Tipo } \\
\text { JBN-IV } \\
\text { JBN-IV } \\
\text { JBN-I } \\
\text { JBN-0 }\end{array}$ & $\begin{array}{c}\text { Média vv } \\
11,25\end{array}$ & $\begin{array}{c}\text { Média Alt } \\
750\end{array}$ \\
\hline \multicolumn{8}{|c|}{ Abaixo de $500 \mathrm{~m}$ (12 e 18 UTC) } \\
\hline $\begin{array}{c}\text { Data } \\
08 / 04 / 02 \\
16 / 04 / 02\end{array}$ & $\begin{array}{c}\text { Hora } \\
18 \\
12\end{array}$ & $\begin{array}{c}\text { Inten.(m/s) } \\
6,1 \\
10,5\end{array}$ & $\begin{array}{c}\text { Alt.(m) } \\
390 \\
300\end{array}$ & $\begin{array}{c}\left.\text { Dir. ( }{ }^{\circ}\right) \\
\text { NE } \\
\text { SW }\end{array}$ & $\begin{array}{c}\text { Tipo } \\
\text { JBN-IV } \\
\text { JBN-0 }\end{array}$ & $\begin{array}{c}\text { Média vv } \\
8,3\end{array}$ & $\begin{array}{l}\text { Média Alt } \\
\quad 345\end{array}$ \\
\hline \multicolumn{8}{|c|}{ Acima de $500 \mathrm{~m}$ (12 e $18 \mathrm{UTC})$} \\
\hline $\begin{array}{c}\text { Data } \\
21 / 04 / 02\end{array}$ & $\begin{array}{c}\text { Hora } \\
18 \\
\end{array}$ & $\begin{array}{c}\text { Inten.(m/s) } \\
12,1\end{array}$ & $\begin{array}{c}\text { Alt.(m) } \\
1100\end{array}$ & $\begin{array}{c}\text { Dir. }\left({ }^{\circ}\right) \\
\text { SE }\end{array}$ & $\begin{array}{l}\text { Tipo } \\
\text { JBN-I }\end{array}$ & $\begin{array}{c}\text { Média vv } \\
12,1\end{array}$ & $\begin{array}{c}\text { Média Alt } \\
1100\end{array}$ \\
\hline
\end{tabular}


a)
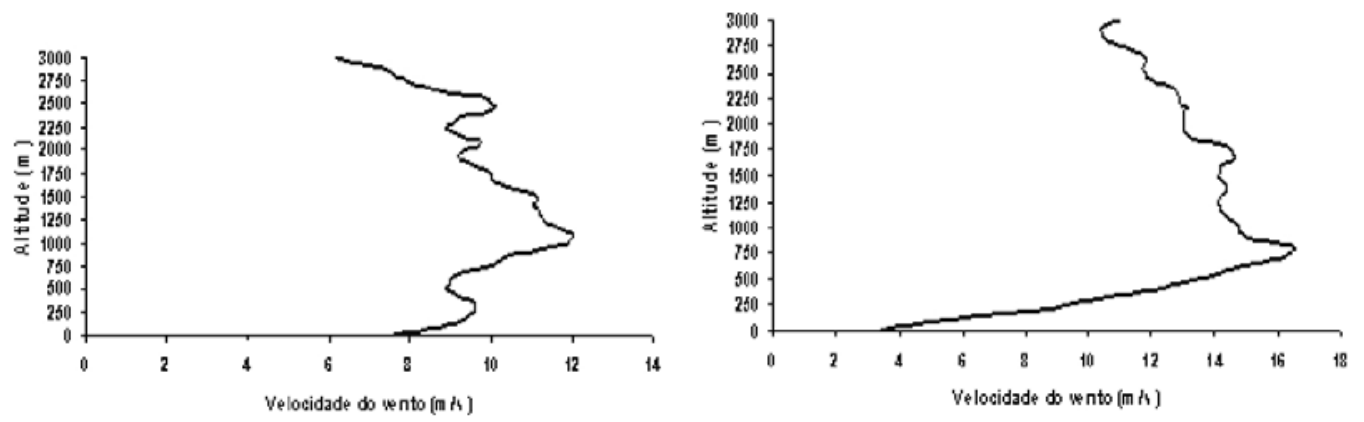

c)

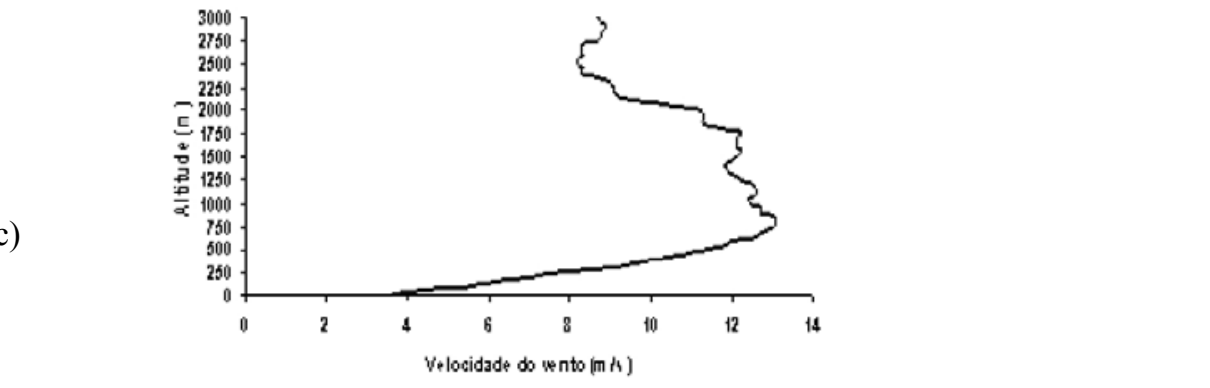

b)

Figure 2 - Vertical profiles of speed of the wind for the days: (a) 04/21/02 at 18UTC, (b) 04/22/02 to the 00UTC and (c) 04/22/02 at 06UTC.

intensity, located above a layer of thermal inversion (with a top of $250 \mathrm{~m})$ as can be see in the Figure $3 \mathrm{~b}$. After 6 hours $(0600$ UTC 2002/04/22) this same LLJ was still active around $850 \mathrm{~m}$ high with an intensity of $13 \mathrm{~m} / \mathrm{s}$ (Figure $2 \mathrm{c}$ ).

Using the diagrams Skew-T Log P of radiosondings made at 18,00 and 0600 UTC on $02 / 04 / 21$ and $02 / 04 / 22$, it is observed that there is a temperature inversion in the vertical profile, the base being a little below the maximum peak of LLJ and the top of the inversion layer located approximately at the level of 950hPa (Figure3b). According to Bonner (1968), the most of the LLJ episodes occurred above the inversion level, according to his two years studies at the Great American Plains.

Figure 4 displays the hodograph curves resulting from the choice of maximum intensity LLJ in all the levels (Table 3) for the 02/04/22 event, showing an almost elliptic format, with its main axis in the direction SE-NW at 1800 UTC, NE-SW at 0000 and $0600 \mathrm{UTC}$, but at $0600 \mathrm{UTC}$ the main axis is in the East-West direction. This orientation indicates predominant LLJ direction in the area of Bragança-Ajuruteua. In agreement with Anderson and Arritt (2001), LLJ occurring at night period rotates mostly in clockwise direction during the months of summer in HN. In the present study a similar behavior was observed for the rainy season (equivalent to the winter).

In agreement with the climatologically study done by Marengo et al (2004), where it was shown that in the months of winter (MJJA) the trade winds are less pronounced next to Equator, and in South America (Douglas et al, 1998), the low occurrence of LLJ is found in the month of April, with maximum intensity around $800 \mathrm{hPa}$.
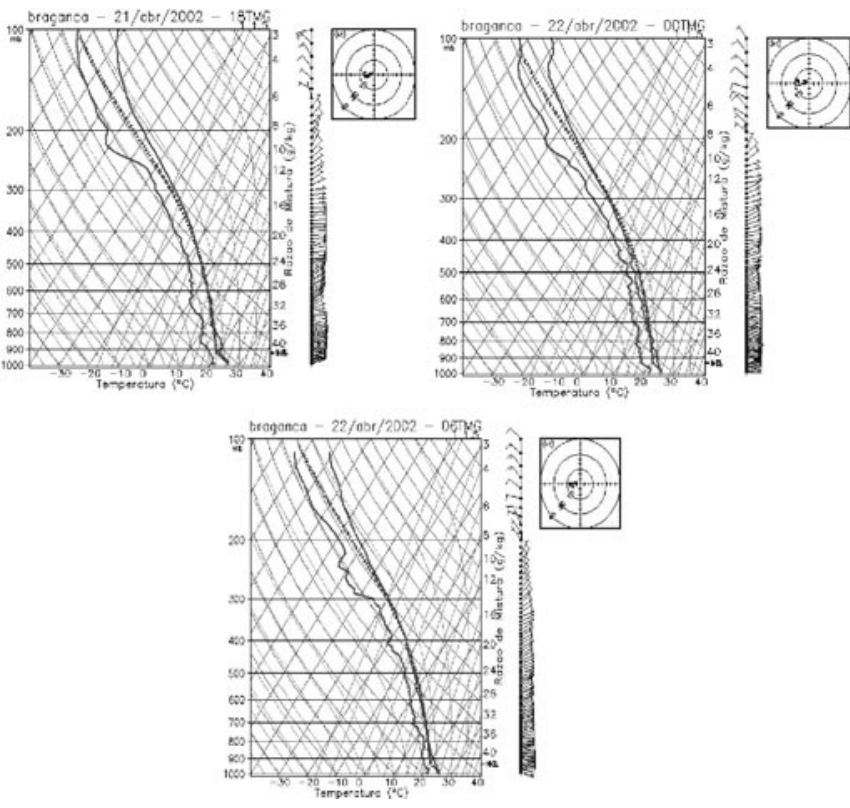

Figure 3 - Diagrams SKEW-T LOG-P for the days (a) 04/21/02 at $18 \mathrm{UTC}$, (b) $04 / 22 / 02$ at $00 \mathrm{UTC}$ and (c) $04 / 22 / 02$ at $06 \mathrm{UTC}$. 

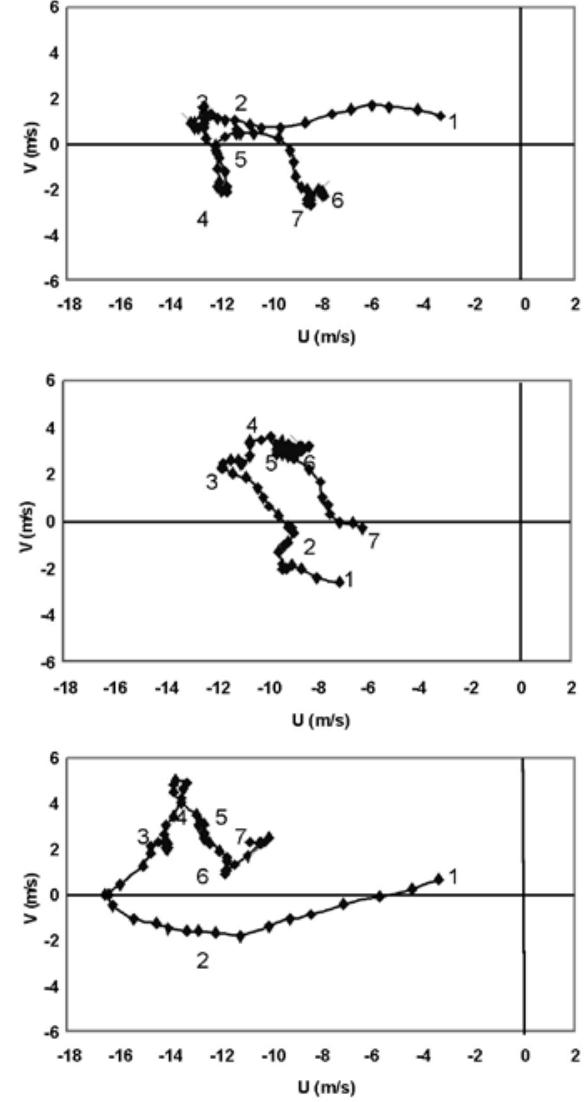

Figure 4 - Hodographys curves for the days (a) 04/21/02 at 18UTC, (b) $04 / 22 / 02$ at 00UTC and (c) $04 / 22 / 02$ at 06UTC.

Table 3 - Relative levels to the altitude values.

\begin{tabular}{|c|c|}
\hline 1 & SUP \\
\hline 2 & 500 \\
\hline 3 & 1000 \\
\hline 4 & 1500 \\
\hline 5 & 2000 \\
\hline 6 & 2500 \\
\hline 7 & 3000 \\
\hline
\end{tabular}

The occurrence of LLJ was observed in the time sequence of the wind velocity, where it is noticed that this JBN stayed for 12 hours with its thickness increasing considerably during the night. On 02/04/21 event at 1800 UTC it is possible already to notice winds above $12 \mathrm{~m} / \mathrm{s}$ at $1000 \mathrm{~m}$ high. At 0000UTC on 02/04/22 it was observed the nucleus with velocity higher than $16 \mathrm{~m} / \mathrm{s}$ and $1500 \mathrm{~m}$ thick, from the base to the top. 12 hours later this LLJ was dissipating having velocities of $14 \mathrm{~m} / \mathrm{s}$ below $750 \mathrm{~m}$ in the point of maxim velocity (Figure 5), which emphasizes the generating mechanisms of this LLJ (inertial oscillation and frictional decoupling nocturne), comparable to that presented by Savijarvi (1991).

In synthesis this LLJ presented a gradual and typical

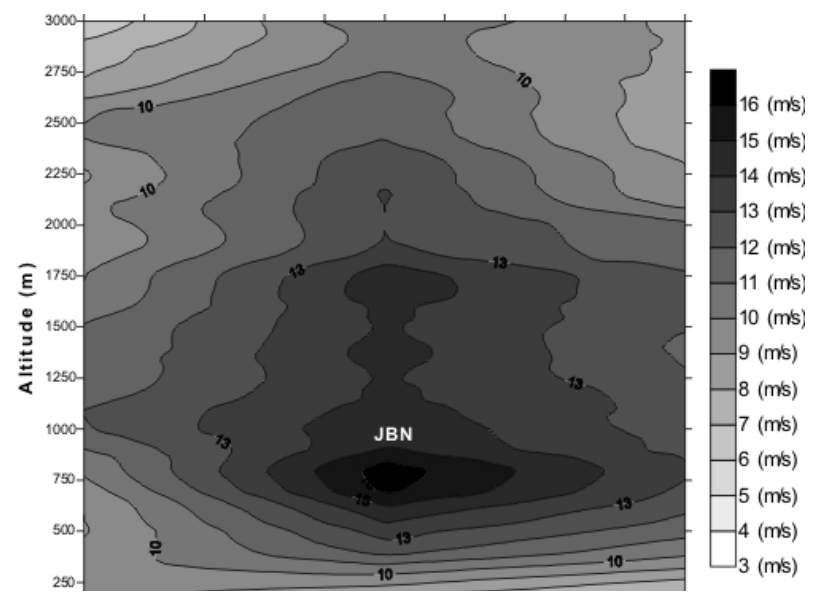

Figura 5 - Temporal Evolution of LLJ of the 04/21/02 at 18UTC to the $04 / 22 / 02$ at $06 \mathrm{UTC}$.

behavior compared to the temporary evolution seen in the literature (Bonner, 1968a). It is formed at the end of the afternoon (1800UTC 02/04/21) where the decline of the vertical mixture is set by the thermal inversion, then a larger intensification phase at 0000UTC on $02 / 04 / 22$, when the maximum wind velocity values were observed. In the following phase, weakness and dissipation of LLJ were observed on the first hours of day (0600UTC 02/04/22), when the radiative heating imposes the destruction of the thermal inversion that supports the LLJ structure. (Mahrt, 1999).

\subsection{Satellite images}

Squall Line associated to the LJJ of $02 / 04 / 22$ was followed through images of GOES- 8 meteorological satellite (Figure 6). In the sequence of satellite images (not presented) the development of a SL can be observed on the north coast of South America, from Maranhão State to Venezuela, moving later southward as far the State of Tocantins, as a squall line of type II Propagation - SLP2 (Cohen, 1989). It is also possible to follow the phases of life cycle of this SL, before, during and after its passage along the coast (Braga, 2004).

This SLP2 was formed around 1745UTC and its best characterizing details showed up after 2045UTC. This SL spread parallel the line of the coast and dissipated around 0715 UTC on next day.

Through satellite images over South America (not presented), intense convective nucleus were observed in the west of the Amazonian region, next to the of Andes Cordillera, Intertropical Convergence Zone (ITCZ) very defined over the Atlantic next the region of formation of SLP2 and a cold front dissipating on the Atlantic South. The good characterization of ITCZ on the Atlantic is favourable to the formation of SLP2 as pointed out by Cavalcanti (1982). 

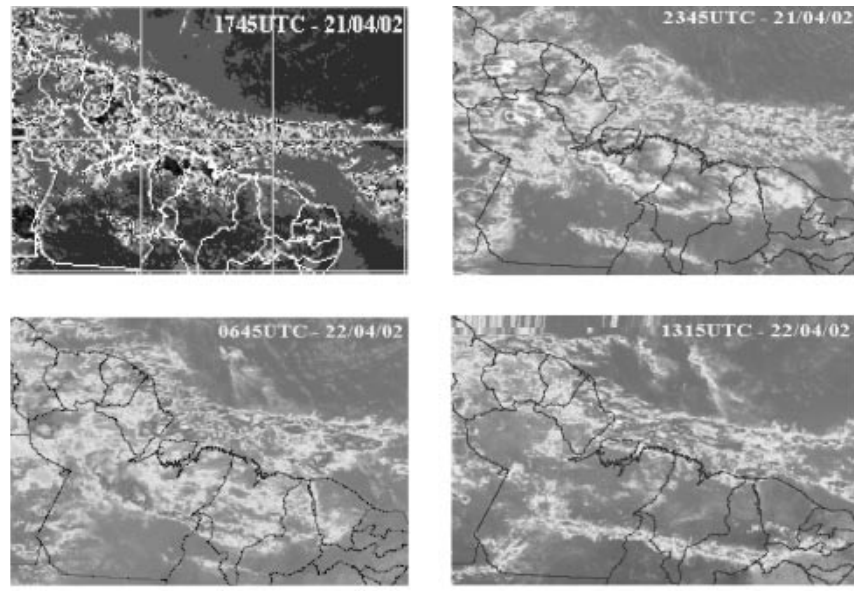

Figure 6 - Satellite images for the period of persistence of SL.

\subsection{Comparison to the Climate Analysis (Climanalise)}

Based on the Bulletin of Monitoring and Climatic Analysis (Climanalise, 2002) for the month of April, 2002, the north region presented a convective activity above the average climatology. The largest ITCZ convective activity was observed over the Equator, approximately between $2^{\circ} \mathrm{N}$ and $2^{\circ} \mathrm{S}$, next to the north and northeast coast of Brazil, contributing to the increase of occurrence of rains in Amapa, Para, Maranhão and Ceara. During several days it was observed that the ITCZ interacted with cyclonic vortices and trough at high levels, as well as, with SL along the north coast of Brazil.

On April, eight cumulonimbus lines or SL were configured along the north coast of Brazil, however, with moderate to weak intensities. Among these occurrences on April 21 at 1745UTC the formation of a SL was showed up next to the Atlantic coast. It was spread like a SLP2 until 0900UTC of the day after or, in other words, it was associated to the marine breeze.

This SL formation spread by $590 \mathrm{~km}$ inside the continent, similar to those studied in the Amazonian region by Garstang et al (1994) and Cohen et al. (1995). This SL has spread parallel to the coast and dissipated around 0715UTC of the next day (Braga, 2004).

Based on the analysis of the wind field and satellite images of the LLJ and SL, it was observed that LLJ might have been one of the preponderant factors responsible for squall line's propagation in the coast of the State of Para. In general the pattern of the LLJ drainage in the north coast, close to Equator, is similar to those found in observations for the same period (Bonner, 1968 and Higgins, 1997).

\section{CONCLUSIONS}

In this work, the observational study of more intense Low Level Jets (LLJ) observed during the rainy period over the north and northeast coast of the Para State and their characteristics, during and after the formation of a SL case are investigated. Data collected during field measurements at Ajuruteua city in Bragança were used.

The results indicated that the selected case of LLJ, located at the north and northeast of Para, was due to the action of 1 - Inertial oscillation and 2 - Superficial baroclinity.

These two physical factors sustained the LLJ with intensities between 10 and $13 \mathrm{~m} / \mathrm{s}$ during the afternoon and between 14 and $16 \mathrm{~m} / \mathrm{s}$ at night, at an average altitude of $800 \mathrm{~m}$ above the surface.

The thermodynamic and cinematic results of this LLJ showed that, its development was related to the loss of energy in the surface, and the largest development was during night period, above the temperature inversion and always directed from $\mathrm{NE}$ to $\mathrm{E}$ at its point of maximum velocity.

Based on satellite images the squall lines propagation showed that during formation the SL and LLJ were more intense over the cost, and six hours later the LLJ largest intensity was over the coast and SL largest intensity was inside the continent. This shows that this LLJ might have been one of the factors of propagation of this SL.

The results presented in this work represent one step further to the understanding of the important mechanisms of LLJ formation and of tropical SL propagation (responsible for $45 \%$ of the precipitation over the N-NE region of the States). Other investigations are necessary to evaluate the connection between these two phenomena to the local and regional environment.

\section{ACKNOWLEDGEMENTS}

This research was accomplished with the support of PPG7/FINEP/MCT, DESMATA and MILENIO LBA. We thanked the Coordinator of the Sub-project of UFPA DESMATA, in making these data available for this study, part of an UFPEL master's degree dissertation. We thank also the Coordination of Improvement of the Personnel of the Higher education (CAPES) for the concession of the master's degree fellowship and to CNPq.

\section{REFERENCES}

ANDERSON, C. J.; ARRIT, R. Representation of summertime low-level jets in the central United States by NCEP-NCAR reanalyses. Journal of Climate, Boston, v. 14, n. 2, p. 234-247, Mar. 2001. 
BONNER, W. D. Climatology of the Low Level Jet. Monthly Wheather Review, Boston, v. 96, n. 12, p. 833-850, Dec. 1968a.

BONNER, W. D.; ESBENSEN, S.; GREENBERG, R. Kinematics of the Low Level Jet. Journal of Applied Meteorology and Climatology, Boston, v. 7, n. 3, p. 339347, Feb. 1968b.

BRAGA, R. H. M.; COHEN, J. C. P. Estudo termodinâmico de casos de linhas de instabilidade no leste da Amazônia. caso 1: linha de instabilidade marítima. In: CONGRESSO BRASILEIRO DE METETEOROLOGIA, 13., 2004, Fortaleza. Anais... Fortaleza: SBMET, 2004. CD.

CAVALCANTI, I. F. A. Um estudo sobre interações entre sistemas de circulações de escala sinótica e circulações locais. 1982. 116f. Dissertação (Mestrado em Meteorologia) - Centro de Previsão do Tempo e Estudos Climáticos, Instituto Nacional de Pesquisas Espaciais, São Paulo, 1982.

CPTEC. Boletim de Monitoramento e Análise Climática. CLIMANÁLISE, São Paulo, v. 17, n. 3, p. 1-44, abr. 2002. Disponível em: http://www.cptec.inpe.br/climanalise/ products. Acesso em: 25, oct. 2004.

COHEN, J. C. P. Um estudo observacional de linhas de instabilidade na Amazônia. 1989. 121f. Dissertação (Mestrado em Meteorologia) - Centro de Previsão do Tempo e Estudos Climáticos, Instituto Nacional de Pesquisas Espaciais, São Paulo, 1989.

COHEN, J. C. P.; SILVA DIAS, M. A. F.; NOBRE, C. A.: Environmental conditions associated with Amazonian squall lines: a case study. Monthly Wheather Review, Boston, v. 123, n. 11, p. 3163 - 3174, Nov. 1995.

DOUGLAS, M. W.; NICOLINI, M.; SAULO, C. Observational evidences of a low level jet east of the Andes during January-March 1998. Meteorologica, Buenos Aires, v. 23, n. 1, p. 63-72, enero. 1998.

FRAQUHARSON, S. J. The diurnal variations of wind over tropical Africa. Quarterly Journal Royal Meteorology Society, Oxford, v. 65, n. 1, p. 165-183, Jan. 1939.

GARSTANG, M.; MASSIE JR., H. L.; HALVERSON, J.; GRECO, S.; SCALA, J. Amazon coastal squall lines, part I: Structure and kinematics. Monthly Wheather Review, Boston, v. 112, n.4 , p. 608-622, Apr. 1994.

HIGGINS, R.W.; YAO, Y.; YAROSH, E.S.; JANOWIAK, J. E.; MO, K.C. Influence of the Great Plains Low Level Jet on summertime precipitation transport over the Central United States. Journal of Climate, Boston, v. 10, n. 4, p. 481-507, May. 1997.

KARAN, H. A. Estudo do Jato de Baixos Níveis de Iperó e das Implicações no Transporte de Poluentes no
Estado de São Paulo. 2002. 182 f. Tese (Doutorado em Meteorologia) - Instituto Astronômico e Geofísico, Universidade de São Paulo, São Paulo, 2002. MAHRT, L. Stratified atmospheric boundary layers. Boundary Layer Meteorology, New York, v. 90, n. 3, p. 375-396, Mar. 1999.

MARENGO, J. A.; SOARES, W. R.; SAULO, S.; NICOLINI, M. Climatology of the Low-Level Jet East of the Andes as Derived from the NCEP-NCAR Reanalyses: Characteristics and Temporal Variability. Journal of Climate, Boston, v. 17, n. 12, p. 2261-2280, June. 2004.

MEANS, L. L. On Thunderstorm Forecasting in the Central United States. Monthly Weather Review, Boston, v. 80, n. 10, p. 165-189, Oct. 1952.

MEANS, L. L. A study of the mean southerly wind-maximum in low levels, associated with a period of summer precipitation in the Middle West. Bulletin America Meteorology Society, Boston, v. 35, n.1 p. 166-170, Jan. 1954.

PAEGLE, J.; NOGUES-PAEGLE, J.; McCORCLE, M.; Õ'BRIEN, C. J.; MILLER, E. Diagnoses and numerical simulation of a low-level jet during ALPEX. Beiträge zur Physik der Atmosphäre, Braunschweig, v. 57, n. 3, p. 419430, Juli. 1984.

SAVIJARVI, H. The United States Great Plains diurnal ABL variation and the nocturnal low level jet. Monthly Weather Review, Boston, v. 119, n.3, p.833-840, Mar. 1991.

SOUSA, A. M. L. Estudo Observacional de Jatos de Baixos Níveis no Litoral Norte e Nordeste do Pará durante o Período Chuvoso e Seco. 2005. 140f. Dissertação (Mestrado em Meteorologia) - Faculdade de Meteorologia, Universidade Federal de Pelotas, Rio Grande do Sul, 2005.

STENSRUD, D. J. Importance of Low-Level Jets to climate: A review. Journal of Climate, Boston, v. 9, n. 8, p. 16981711, Jan. 1996.

STIVARI, S. M. S. Estudo da brisa lacustre do Lago de Itaipu. 1999. 196 f. Tese (Doutorado em Meteorologia) - Instituto Astronômico e Geofísico, Universidade de São Paulo, São Paulo, 1999.

WIPPERMANN, F. Numerical study on the effects controlling the Low-Level Jet. Beitrage Zur Physik der Atmosphere, Hamburg, v. 46, n. 22, p. 137-154, Okt. 1973.

WITHEMAN, C. D.; XINDI, B.; ZHONG, S. Low level jet climatology from enhanced rawinsonde observations atmosfera a site in the southern great plains. Journal of Applied Meteorology, Boston, v.36, n. 10, p. 1363-1376, Oct. 1997.

WU, Y. H.; RAMAN, S. Effect of Land-Use Pattern on the Development of Low-Level Jets. Journal of Applied Meteorology, Boston, v. 36, n. 5, p. 573-590, May. 1997. 